\title{
MÜZEDE SANAL GERÇEKLİK UYGULAMALARI: BİR ÖRNEK ÇALIŞMA OLARAK KAPLUMBAĞA TERBIYYECISII
}

\author{
Betül TANRIKULU \\ İzmir Bakırçay Üniversitesi, Türkiye \\ https://orcid.org/0000-0002-0181-3180 \\ betultanrikulu@gmail.com \\ Aynur KARAGÖL \\ Yıldız Teknik Üniversitesi, Türkiye \\ https://orcid.org/0000-0001-9247-2483 \\ aynurkaragol@gmail.com
}

ÖZ

Ülkemizde ve dünyada yeni gelişen bir alan olarak Sanal Gerçeklik (SG)'in teknolojik gelişmelere koşut olarak ilerlediği görülmektedir. 21.yy. başlarında hareketli görüntünün işlenebilmesiyle interaktif cihazların üretilmeye başlanması alan için ilk basamak olarak kabul edilmektedir. Çalışmada, öncelikle sanal gerçeklik tanım ve kavramsal olarak incelenmiş ardından sanal gerçekliğin tarihsel geçmişine ve dünyadaki farklı müzelerdeki üretim örneklerine yer verilmiş̧ir. Devamında Türkiye'deki müze ve diğer kurumsal üretimlere değinilip örnekler ile açıklanmıştır. Son bölümde ise Türk resminde oldukça bilinen ve sevilen Osman Hamdi Bey'in Kaplumbağa Terbiyecisi isimli eserinden yola çıkılarak tasarlanan Pera Müzesi'ndeki "Osman Hamdi Bey'in Dünyasına Yolculuk" isimli Sanal Gerçeklik deneyiminin değerlendirilmesi amacıyla katılımcılarla görüşmeler yapılmıştır. Araştırma, nitel araştırma yöntemi (elektronik-posta görüşme) tekniği ile gerçekleştirilmiştir. Bu çalışmada Pera Müzesi’nde Kaplumbağa Terbiyecisi isimli tabloyu SG yolu ile deneyimleyen Görsel Sanatlar alanlarında uzman 6 katılımcıya yöneltilen 4 soru ile desteklenmektedir. Sorularda deneyimin kendisi, sanata katkısı ve sanat alanındaki geleceğinin katılımcılar tarafından nasıl görüldüğü anlaşılmaya çalışılııştır. Amaç; SG, sanata ve sanat eserine yeni bir bakış açısı sağladığı, müze ziyaretçisinin ilgisi üzerindeki etkisini, aynı zamanda tek boyutlu olan resmin tualinin bize gösterdiğinden fazlasını vadetmesiyle SG'nin esere müdahalesinin nasıl karşılandığını anlamaktır.

Anahtar Kelimeler: Sanal Gerçeklik, Müze, Tasarım

\section{VIRTUAL REALITY APPLICATIONS IN THE MUSEUM: TURTLE TRAINER AS A CASE STUDY}

\begin{abstract}
It is seen that Virtual Reality (SG), as a newly developing field in our country and in the world, is progressing in parallel with technological developments. $21^{\text {st }}$ century. Beginning to produce interactive devices by processing the moving image at the beginning is considered as the first step for the field. In the study, firstly, virtual reality was examined in terms of definition and concept, and then the historical
\end{abstract}


background of virtual reality and production examples in different museums around the world were included. Continued mentioned and in museums in Turkey and other corporate production is explained with examples. In the last part, interviews were made with the participants in order to evaluate the Virtual Reality experience named "Journey to the World of Osman Hamdi Bey" at Pera Museum, which was designed based on Osman Hamdi Bey's work titled The Tortoise Trainer, which is well known and loved in Turkish painting. The research was carried out with qualitative research method (e-mail interview) technique. In this study, it is supported by 4 questions directed to 6 participants who are experts in the field of Visual Arts who experienced the painting called The Tortoise Trainer in Pera Museum through SG. In the questions, the experience itself, its contribution to art and how its future in the field of art was seen by the participants were tried to be understood. The purpose; SG is to understand how SG's intervention in the work is met by providing a new perspective to the art and the work of art, its effect on the museum visitor's interest, and at the same time promising us more than the one-dimensional painting canvas shows us.

Keywords: Virtual reality, Museum, Design

\section{GíRiș}

Sanal Gerçeklik, gerek akademik gerekse özel sektörde araştırılan ve geliştirilen bir alan olarak popüler bir konudur. Literatürde konuyla ilgili pek çok yayın mevcuttur. Eğitim, emlak, oyun gibi sektörlerde yeni proje konuları için doğru bir uygulama alanı olarak sanal gerçeklik öne çıkmaktadır. Özellikle son yıllarda sayıları hızla artan müzeler; bazen tarihsel bir sahnenin canlandırılmasında bazen de tanınan bir resmin analizinde SG'yi kullanmaktadır. SG gibi teknolojiler müzecilik alanında detaylı görme, tarihi bir atmosferi duyumsama gibi imkanlar sağlamaktadır. Ayrıca SG tasarımları, kamuoyunun ilgisini toplama, basın ve sosyal medyada zengin bir içeriğe dönüşmektedir. Dünyada ve ülkemizde müzecilik açısından tasarım örnekleri vardır. Büyük teknoloji firmalarının ürün bazında üretim yaptığı alanda proje noktasında ülkemizde, dünyadakine paralel gelişim çabaları mevcuttur. Sanat ve müzecilik alanında SG kullanımının bir örneği olarak bu çalışmada Pera Müzesi'nde Kaplumbağa Terbiyecisi isimli tabloyu SG yolu ile deneyimleyen Görsel Sanatlar alanlarında uzman 6 katılımcıya yöneltilen 4 soru ile nitel araştırma yöntemi elektronik-posta aracılığıyla gerçekleştirilen e-görüşme yapılmıştır. Sanat eseri, teknoloji ve kullanıcı deneyimi bağlamında alana katkısı ve etkisi irdelenmektedir.

\section{SANAL GERÇEKLİK (SG) NEDİR?}

Sanal, "gerçekte yeri olmayıp zihinde tasarlanan, mevhum, farazi, tahminî" (tdk.gov.tr) şeklinde tanımlanırken; İngilizce eş anlamlı hali virtual kavramı ise 'virtue' erdem kelimesinden türetilmiştir. Erdem kelimesi ise genel manada ahlakın övdüğü iyi olma, alçak gönüllülük, yiğitlik, doğruluk vb. niteliklerin genel adıdır (tdk.gov.tr). Gerçek olanın küçük bir farklarla aktarılması demekte olan 'virtue' (oxfordlearnersdictionaries.com). Gerçek dünyaya benzeyen ama esasında gerçek olmayan bir dünyayı tanımlamaktadır (Tablo 1). Bu nedenle sanal dünyayla ilgilenen profesyoneller gerçek dünyayı Gerçek Gerçeklik (Real Reality) olarak adlandırmaktadır. Gerçek bir ortamı, 360 derece bir video çekimiyle tasarlamak akla gelen ilk SG ortamı yaratma yöntemidir. Diğer yöntem ise bilgisayar ortamından 3 boyutlu bir tasarımla 360 derece bir mekân oluşturmaktır. Bazı çalışmalarda ise bu iki yöntem birlikte kullanılarak sanal ortam hazırlanmaktadır.

\section{a. SANAL GERGERÇEKLİ'İN TEMEL KAVRAMLARI}

İmmersiyon (Immersive); Teknolojinin katkısıyla üretilen sanal ortamın katılımcı bireyin duyularına etkin bir şekilde nasıl gerçeklik etkisi yaptığını tanımlamaktadır.

Var Olma hali/bulunma hali (Presence); Beş duyu üzerine sanal gerçeklik ile bilgisayar ve deneyimleyici arasında etkileşim oluşmaktadır. Bu etkileşimin gerçekçi olması ve kişinin hissedebilmesi rada olma haline sahip olmanız gerekiyor ve bunun doğal bir biçimde gerçekleşmesi işin başarısını göstermektedir. 


\section{b. SANAL GERGERÇEKLİK'IN BILLEŞENLERİ}

Baş üstü görüntüleyici (Head mounted display); Başa takılan görüntüleyici sayesinde 360 derece görüş sağlanmaktadır.

Ak1llı eldivenler (smart gloves); giyilen eldivenlerle etkileşimin oluşturulur.

Kumanda (Joystick); sanal olarak hareket etmek seçim yapmak gibi fonksiyonlar gerçekleştirilmektedir.

Çeşitli aparatları kullanmak ve aynı zamanda girilen 3B'lu dünyaya adapte olmak konusu kullanıcıyı zorlarken belli bir efor gerektirmektedir. Bu anlamda bir adaptasyon gerektirmektedir.

Tablo 1. Gerçeklik, Gerçekliğin farklı varyasyonları

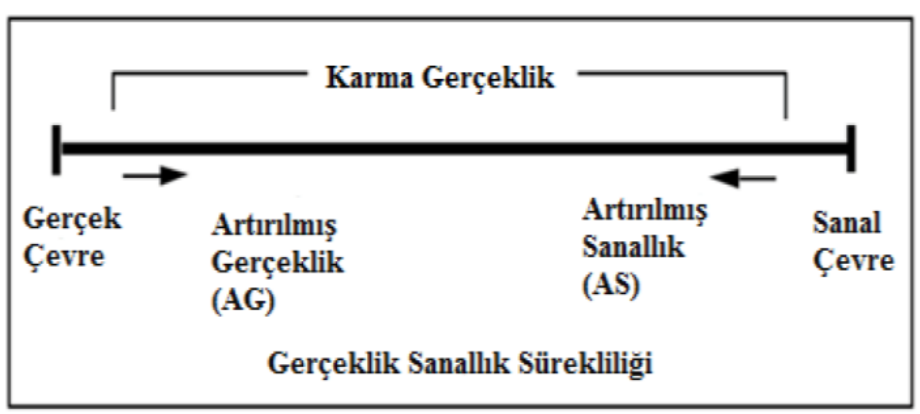

Kaynak: Milgram \& Kishino (1994).

\section{SANAL GERÇEKLIIK'IN GEÇMIŞi VE ÖRNEK ÇALIŞMALAR}

Sanal Gerçeklik, teknolojik gelişmelerin getirdiği bir mecra olarak bilinmekle birlikte, insanlık tarihi açısından mekan ve algı konuları hakkında felsefesi yapılan mağara ile ilişkilendirilmektedir. Platon'un mağara alegorisi insanlık tarihinde mekan algısının başladığı ilk yapıdır. Her yeri kapalı bir kutu olan mağara mefhumu ve 1şıkla oluşan nesnenin gölgesi ile ilişkisi algı meselesini anlamlandırmakta kullanılmaktadır. Aynı zamanda SG'nin günümüzdeki mekan meselesine de felsefi bir dayanak oluşturmaktadır. Mağarada yaşamak zorunda olan kişi, ateşin 1şığı yardımıyla dış dünyada cereyan eden durumları birer yansıma olarak onların gölgelerinden tanır. Gerçek olarak kabul edilen gölgeler aslında birer yanılsamadan ibarettir. Onun, gerçek diye kabul ettiği şeyin esasında gerçeğin birer gölgesi olduğunu ancak o mağaradan çıkabilirse görebilir. Platon'un, 'Devlet' isimli kitabında yer verdiği mağara simgesi aslında dünyada sıradan insanın mekansal durumunu anlatmaktadır. O bir tutsaktır ve kusurlu bir hayat yaşar ancak Platon'un 'idealar' diye tanımladığı 'kusursuz ve değişmez' e ulaşırsa gerçek olana kavuşur. Sanal Gerçeklik’te tıpkı mağara miti gibi kullanıcısına gördüğü inandığı bir dünya verirken bunun gerçek olmadığını unutturmaktadır. Bu dünya bazen tamamen gerçek dünyanın bir kopyasıdır. Bazen de tamamen bir hayal ürünü tasarımdır. Esasında mimaride özellikle dini yapı duvarlarının ve tavanının resimlerle donatılması önemli bir örnek olarak tarihi binalarda karşımıza çıkmaktadır. Bu tasarımlar, 360 derece üretimlere ilham kaynağı olmuştur. Eserler, ziyaretçinin çevresinin donatıldığı görsel şöleniyle dikkati toplamakta ve bir alan bütünlüğü yaratmaktadır.

Sanal gerçekliğin 21.yy'da geldiği noktaya yani SG'nin tarihine bakıldığında; önceleri projeksiyon gibi yöntemlerle oluşturulmaya çalışılan 360 derece atmosferin sonraları mucitler tarafından yeni makinelerle gelişmesine, ardından teknolojik ilerlemenin hız kazanmasıyla, laboratuvarlarda daha kullanışlı yeni cihazların prototipleri ile ilerlediğini görmek mümkündür. Bu gelişmeler sinema, fotoğraf, bilgisayar gibi yaratıcı sanat eserlerinin üretildiği mecralara koşut bir gelişme gösterdiği anlaşılmaktadır. 


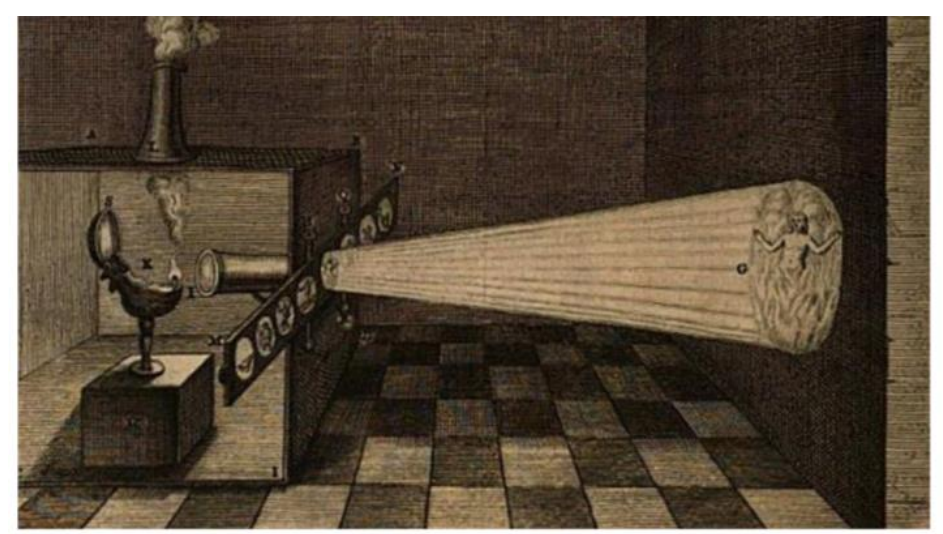

Resim 1. Laterna Magica

Kaynak: URL-1 (2020).

Bir görüntüyü projekte ederek bir yere yansıtma fikrini 15. yy.'da Étienne-Gaspard Robert "Laterna Magica" isimli cihazın icadıyla gerçekleştirmiştir (Resim 1). Fransız Devrimi sırasında, raylara monte edilen iki fenerden sayesinde nasıl projeksiyon yapılacağını keşfetmiştir. Seyircilerin karanlık bir zindana hapsolduğu ve ürkütücü ses efektleri ve hayalet sesleriyle çeşitli boyutlarda hareketli yansıtılmış görüntülere maruz kaldığı 'Phantasmagoria' adlı doğaüstü görünen korkutucu şovlar gerçekleştirilmiştir. (URL-1) Yazılan bir metin üzerinden görüntü üretilerek perdeye yansıtılması ilk olarak Fransız Lumière Kardeşler tarafından gerçekleştirilmiştir. Lumière Kardeşler ilk sunumlarını 22 Mart 1895'te Paris'teki Societe d'Encouragement pour I'Industrie National'e gerçekleştirdiler (Özuyar, 18-19). Ekranın üzerinde gördügüumüz bir şeye inanılması meselesi ilgi çekicidir; çerçeve içinde ekrana bakarken insanlar gördüklerini inanmayı tercih ederler. İnançsızlığın isteyerek askıya alınması (suspension of disbelief), olarak tanımlanan bu durumu, spekülatif bir kurgu çalışması gibi gerçeküstü bir şeye zevk uğruna inanmak demektir. Eleştirel düşünce veya mantıktan kasıtlı olarak kaçınmak gerekmektedir. Projeksiyonla tasarımın mekana yansitılması ve sesle desteklenmesiyle duyumsanan sanal ortam çalışmalarını, yeni makine icatları ve kullanımları izlemiştir.

1960’ların ilk yıllarında Amerikalı görüntü yönetmeni ve mucit Morton Heilig; sürükleyici, çok duyulu, mekanik, multimodal tasarımının bir prototipini yapmıştır. "Senseroma" adı verilen bu cihaz (Şekil 2), içinde gösterilmek üzere beş kısa filmden oluşmaktadır. Heilig, 1955'te "Geleceğin Sineması" başlıklı makalesinde çoklu duyusal alan (multi-sensor theater) vizyonunu ve tasarladığı makineyi anlatmaktadır. 1962'de Heilig'in, bu buluşu, sanal gerçeklikte en eski işlevsel çabalardan biri olarak kabul edilmektedir (URL-2). Birkaç yıl sonra yeni bir makine çalışması Amerika'nın üniversite laboratuvarlarından birinde yapilacaktır.

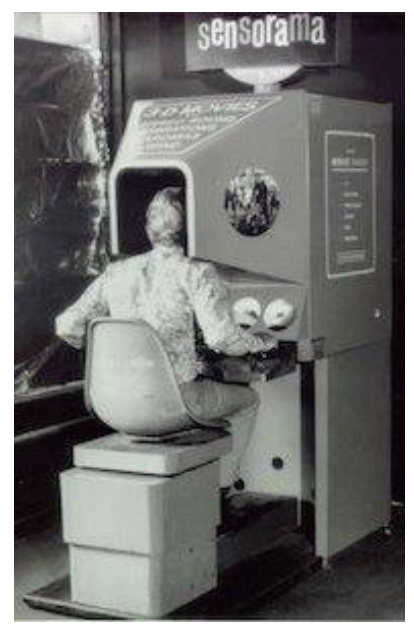

Resim 2. Senseroma

Kaynak: Heiling (1962). 
Ivan Sutherland, MIT Lincoln Laboratuvar'ında 1966 ve 1967 yılları arasında 3 boyutlu gösterim deneyleri yapmıştır. Çalışmanın neticesinde Demokles'in Kılıcı "The Sword of Damocles" adını verdikleri (Resim 3) 3 boyutlu gözlem sağlayan bir çalışma ortaya çıkmıştır. Sutherland, "A head Mounted Three Dimensional Display" makalesinin sonuç bölümünde çalışmasını şöyle özetlemiştir.

"Şimdiye kadar yaşadığımız en büyük sürpriz, kullanıcıların iyi stereoya olumlu tepkisidir. İki tüplü optik sistem, her bir göze bağımsız görüntüler sunarken farklı kullanıcıların farklı göz bebeği ayrımlarına uyum sağlamak için mekanik bir ayarlama yapmamız gerekmiştir. Test programlarındaki yazılım ayarlamaları, stereo hesaplamalar için kullanılan sanal göz ayrımını ayarlamamıza da izin verir. Bu iki ayar ile çok iyi stereo sunumlar elde etmek oldukça kolay. Stereo görüş yeteneğine sahip gözlemciler, elde edilen görüntülerin gerçekçiliğine eşit şekilde dikkat çekmişlerdir."

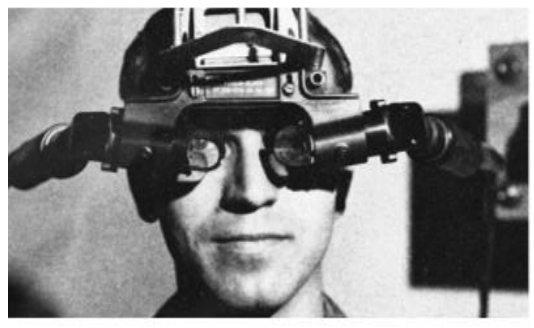

Resim 3. Ivan Sutherland'ın icadı Demokles'in Kılıcı isimli gözlük

Kaynak: Martirosov \&amp; Kopecek (2017).

Sutherland'ın çalışmaları sonrasında 70'li 80'li yıllarda büyük bir gelişme görülmezken 90'lı yıllara geldiğimizde hızlı gelişmelerin olduğu ama cihaz ücretleri, kullanım pratiği sorunu gibi sebeplerle yaygın bir kullanım imkanının oluşmadığı bilinmektedir.

Martirosov ve Kopecek (2017), 90'lı yıllardaki sanal gerçeklikle ilgili gelişmeleri şöyle özetlemektedir; 1990'lı yıllara boyunca halkın erişebildiği SG cihazlarını görülmeye başlanmıştır. 1993 yılında gözlüklerle vizörden kafa takibi, stereo ses ve LCD ekranları destekleyen prototip gözlüklerin bulunduğu konsol tasarımı ve SG kulaklıklar piyasaya sürülmüştür. Sonrasında gerçek 3B grafikleri görüntüleyebilecek ilk taşınabilir konsol 3B oyun konsolu 1995'te yapılırken düşük fiyatlara rağmen, grafiklerdeki renk eksikliği ve yazılım desteği eksikliği nedeniyle ticari bir başarısızlığa uğramıştır. 2010 yılına gelindiğinde, yeni bir prototip 1şı̆̆ 1 görülmüş ve 2014 yılında bir video oyun konsolu için SG başlı̆g 1 olan oyun duyurulur ve kendin yap bir stereoskopik görüntüleyici olan bu çalışma hayata geçirilmiştir. 2014 yılında sosyal medya ağı devi Facebook, alana yatırım yaparak bir markayı satın almış bu durum, sanal gerçeklik teknolojisinin iddialı bir alan olacağının işareti olarak görülmüştür (Liu1, Zhang vd.: 2018). Akıllı telefonlar markaları 2015 yılında, kumandalı SG başlığını çıkararak sektöre yatırım yapmıştır. VR teknolojisini yatırımcılar için cazip kılan yönü pek çok alan için kullanışlı olmasından kaynaklanmaktadır. Tıp, askeri, mühendislik gibi büyük yatırımlar gerektiren alanlar için yaygın bir kullanım yelpazesiyle gelişim potansiyeline sahip olduğu görülmektedir. Ancak yatırımların büyük olması ve kullanım yaygınlığının maliyetler açısından dar olması sektörün gelişmesini engellemektedir.

Türkiye'de diğer ülkelerde olduğu gibi SG'nin oyun sektörünün etkisiyle ilk tasarım örnekleri bu sektörde görülmektedir. Bir teknoloji geliştirme şirketinin elli farklı ülkede üniversitelerle işbirliği sağladığı laboratuvarlarının ilki Türkiye'de kurulmuştur. Akademik bir şekilde üniversitelerin bu konuya eğilmesi ilk olarak Bahçeşehir Üniversitesi bünyesinde kurulan VR First BAU laboratuvarı ile olmuştur. Bu girişim; ekipman ve akademik altyapıyı birleştirerek yeni fikirlere ve kişilere açık demokratik yapı sunmaktadır. VR First, direktörü laboratuvarın yeni kurulduğu 2016 yılında verdiği bir röportajda geçmişi uzun yıllara dayanan sanal gerçeklik çalışmalarının yeni donanım ve ekipmanlarla son birkaç yıldır dünyada ciddi biçimde çalışıldığını ve bu anlamda geç kalmadan gelişmelere dahil olunacağını vurgulamıştır (URL-3). Bu ilk girişimin devamında İstanbul Aydın Üniversitesi Yeni Medya Araştırmaları çatısı altında VR-LAB (2017) adıyla ve İstanbul Kalkınma Ajansı desteğiyle Koç Üniversitesi (2019) SG laboratuvarları kurulmuştur. 
Akademik yeni girişlerin dışında bazı reklam ajansları kullandıkları tanıtım yöntemlerinin yanında yeni bir medium olarak SG'yi kullanmaktadır. Ayrıca sadece sanal gerçeklik artırılmış gerçeklik ve insan bilgisayar etkileşimi üzerine eğitim, iş sağlığı gibi farklı alanlarda projeler üreten teknoloji şirketleri ülkemizde mevcuttur. Bir telekomünikasyon firmasının araba ve telefon etkileşimi üzerine ürettiği SG projesidir. Gerçek araba koltuğuna oturan kullanıcılar bir simülasyon desteğiyle SG gözlük kullanarak araç ile telefon etkileşim deneyimini tıpkı yolda gerçek bir sürüş tecrübesine sahip oluyorlar. Böylece üretilen yeni tasarım potansiyel kullanıcısıyla buluşmaktadır (Resim 4).
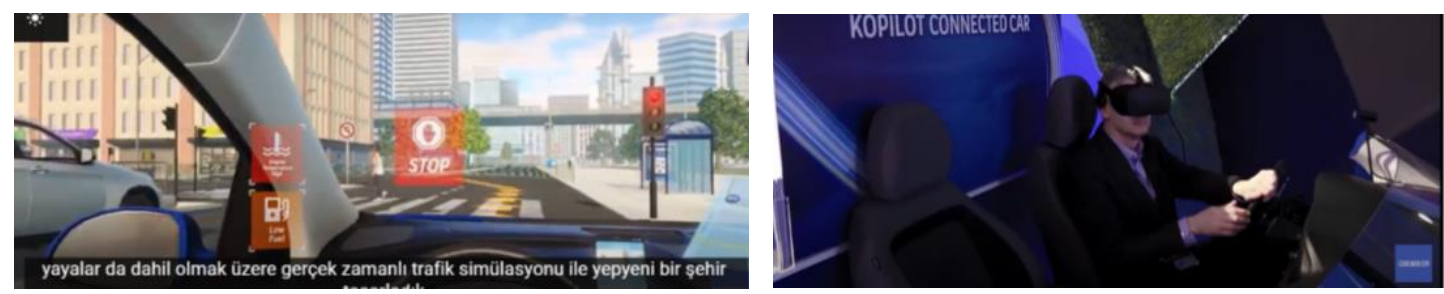

Resim 4. Gerçek zamanlı simülasyon ile telefon ve araba etkileşimli bir destek tasarımının anlatımı SG ile yapiliyor.

Kaynak: URL-6 (2019).

\section{MÜZELERDE SANAL GERGERÇEKLIK UYGULAMASINDAN ÖRNEKLER}

Son yıllarda, sanal gerçeklik (SG) kullanımı önemli ölçüde artmıştır ve hayatımızın birçok farklı alanında yer aldı. Müze; Eski Yunan Kültüründe müzeler, güzel sanatları, edebiyat ve ilimleri koruduklarına inanılan, "Mousa" için inşa edilen ve inananların bağışlarıyla toplanan eserlerin sergilendiği tapınakları temsil eden, hayali ülke Pieria'nın ilham perilerinin evidir. Antik dönemde resim ve heykelin müzeleri olmadığı gibi sanatta itibar görmez ve müzeler katına kabul edilmez. Sanatın müzelere girebilmesi için, ortaya çıktığ1 18. yüzyılı bekleyecektir (Erbay, 2011, 5-6). Müzelerde teknolojik gelişimin etkisi ile birlikte kullanılan araçlardan biri de sanal gerçeklik teknolojisidir. Günümüzde teknoloji çok hızlı bir şekilde değişmekte ve gelişmektedir. Akıllı telefonlar, tabletler, bilgisayarlar, çok boyutlu görsel-işitsel cihazlar, vb. yeni aletler ve uygulamalar geliştirilmiştir. Bu cihazlar internet ile birleşerek daha da gelişmiş ve gerçek gibi görünen sanal ortamların oluşmasına imkan vermiştir. Böylece, artırılmış gerçeklik ve sanal gerçeklik teknolojisi müze ekosistemine dahil olmuştur. Bu teknoloji eğitim, tıp, eğlence, yiyecek-içecek, pazarlama, askeri, mimari, müze vb. alanlarda kullanılmaktadır (Demirezen, 2019, 1). Teknolojik sergileme yöntemleri müze sektörüne de dahil edilerek, ziyaretçilerin sanatı deneyimleme ve algılamasını biçimsel olarak etkilemektedir. Sanal gerçeklik gözlüğü kullnıcıyı tamamen yeniden üretilmiş sanal bir ortama aktarmaktadır. Kulaklık ve algı cihazlarıyla desteklenen bu gözlükler kullanıcısına yeni bir ortamda olmayı ve kendi gerçekliğinden soyutlanmayı vaad etmektedir. (Yengin ve Bayrak, 2017, 109)

Dünyadaki ziyaretçi sayısının ve tanınırlığının fazla olduğu müzelerden örnekler seçilerek çalışmaya dahil edilmiştir. Louvre (Paris), Tate Modern (Londra), Finlandiya Ulusal Müzesi (Finlandiya) ülkelerinde bulunan müzelerden örnekler incelenmekle birlikte Türkiye'den kültürel etkinliklerden örneklere yer verilmiştir. Müzelerin teknolojik yenilikleri benimseme ve dijital çağın zorluklarına uyum sağlama girişimiyle müze ortamlarında sanal gerçeklik kullanımında önemli bir artış olmuştur. 


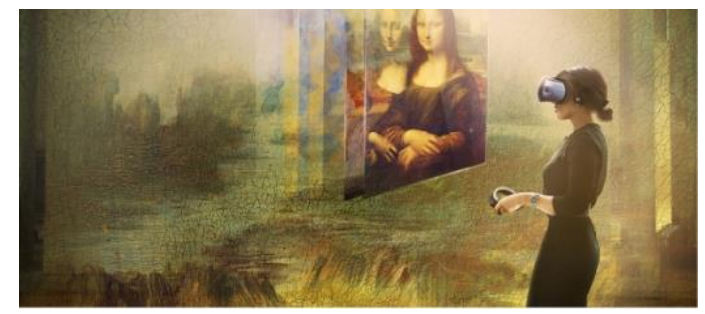

Resim 5. Louvre Müzesi ilk sanal gerçeklik deneyimini Mona Lisa

Kaynak: Pressreader (2019).

Leonardo da Vinci, Mona Lisa (Fransizca Joconde) olarak bilinen Francesco del Giocondo'nun karısı Lisa Gherardini'nin portresi, Paris, Louvre Müzesi sergilenmektedir ((URL-4) Mona Lisa: Beyond the Glass, Musée du Louvre tarafından sunulan ilk sanal gerçeklik (SG) deneyimidir (Resim 5). Napoléon Hall'da 24 Ekim 2019-24 Şubat 2020 tarihleri arasında görüntülenen sanal gerçeklik deneyimi, müzenin Da Vinci’nin ölümünün 500. Yıldönümü anısına ünlü ressamın sergisinin bir parçası olarak sunulmuştur.

Müze, sanal gerçeklik deneyimini bir teknoloji firması ve müze işbirliği ile ziyaretçileriyle buluşturmuştur. İlk deneyimi Rönesans döneminde Floransa'da Leonardo da Vinci tarafından kavak bir pano üzerine Sfumato tekniği ile resmedilen16. yüzyıl yağlı boya portresi Mona Lisa'dır (Gombrich, 2013).

Hergün 20.000'den fazla kişi tarafından ziyaret edilen eser, Louvre'daki Salle des États'de kırılganlığından dolayı kalıcı olarak koruyucu kılıf içinde tutulmaktadır (URL-5). Müze, Da Vinci'nin çalışmalarının retrospektifini sunarken sanal gerçeklik uygulaması sayesinde ziyaretçilere kişisel bir deneyim sunmaktadır (Resim 6).

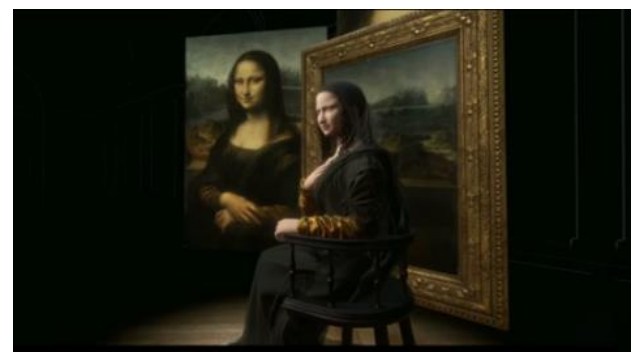

Resim 6. Ziyaretçiler, VR deneyimi ile birlikte Sanat Eseri'nin arkasındaki hikayeye tanıklık etmektedirler.

Kaynak: Pressreader (2019).

Ziyaretçiler, sanal alandaki başyapıtla tek başına, boya katmanından görülen ahşap panelin dokusu ve panelin bir zamanlar çatlayarak ustaca restore edildiği izler de dahil olmak üzere bu ünlü yağlı boya tablonun canlı ayrıntılarını gözlemlenmektedir. SG deneyimi, hareketli görüntü, ses ve etkileşimli tasarımı birleştirerek ziyaretçilere Da Vinci'nin eserine, dünyasına tanıklık edilmektedir. Ziyaretçiler, sanal gerçeklik deneyimi ile salt izleyen olma halinden ayrılarak esere dahil olma sürecine geçmektedir. Bununla birlikte eserin yaratılma anına, geçmişte nasıl göründüğüne, ışığa ve neme maruz kalması nedeniyle 500 yıldan fazla bir süredir nasıl değiştiğine dair eser hakkındaki hikayeye tanık olmaktadır. Deneyimin anlatı bileşeni, eserin kimliği hakkında daha fazla bilgi vererek ünlü Mona Lisa hakkındaki birçok efsaneyi ortadan kaldırarak ve görünüşünün sosyal statüsünü nasıl gösterdiğine dair ek ayrıntılar sunmaktadır. Sanal gerçeklik deneyimi, ziyaretçilerin görebildiğinden daha fazlasını ortaya çıkaran yaratıcı hikaye anlatımı yoluyla sergilenen Da Vinci ve başyapıtlarla etkileşimini tamamlamayı ve geliştirmeyi amaçlamaktadır. 


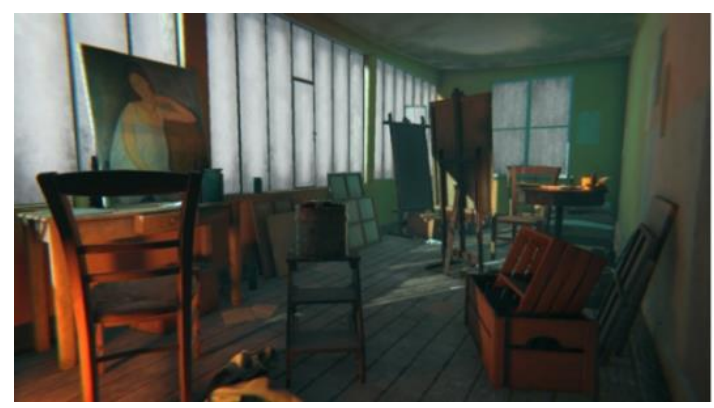

Resim 7. Amedeo Modigliani'nin stüdyosu

Kaynak: URL-6 (2020).

Londra'da bulunan Tate Modern Müzesi 2018 yılında Amedeo Modigliani'nin kapsamlı retrospektifinde, sanatçının stüdyosunu Paris’te bulunan ve 100 yıldır korunan gerçek stüdyosunu sanal gerçeklik desteği ile ziyaret etmektedirler (Resim 7). Bu deneyim ile birlikte Modigliani'nin çalışma alanı yeniden yaratılmaktadır. SG Gözlük ile gerçekleştirile deneyim, belgesel materyallerini ve sanatçının kendi eserlerini inceleyerek yeniden tasarlanmış bir sanal bir deneyim sağlamaktadır. Projeksiyonda bulunun her bir nesnenin (bir kutu sardalya, bir sigara paketi ve 1şığın odaya girişi gibi), gerçek mekanla olgusal bağlantısı sunulmaktadır.

Amadeo'nun resimleri figürlerinde ve portrelerinde (Resim 8) çizgiler ön planda olarak daha çok portrelerden ve tekli kompoze edilmiş figürlerden ibaret olduğu görülmektedir ki figürasyonlarında görülen gotik bir uzatmalarla ressamın portrelerinde insan vücuduna, çehresine verdiği ifadede ince bir manierisme (yapmacık), hasret dolu bir gevşeme vardır: Başlar hafifçe eğilmiş, yüzler değişmiş, gözler durgun bir ümitsizlik içinde ve badem şeklinde resmedilmiştir (Hourticq \& Toprak,1967).

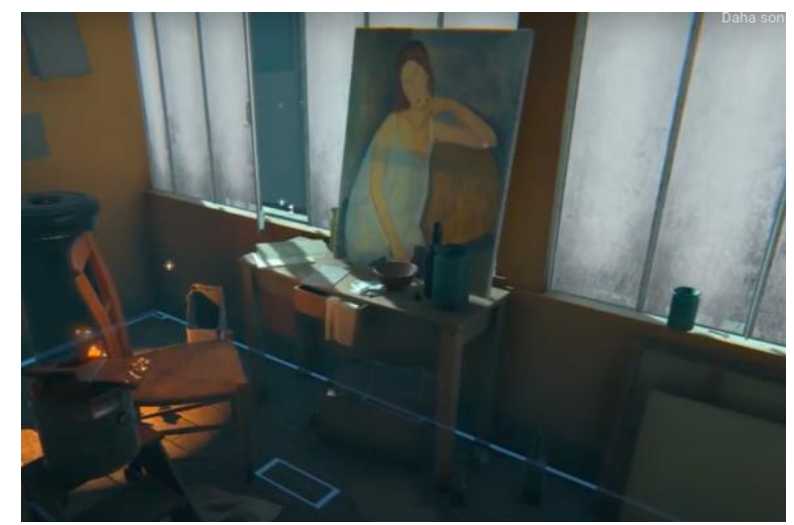

Resim 8. Modigliani VR: The Ochre Atelier

Kaynak: URL-7 (2020). 
British Museum gibi son derece prestijli kurumlar da dahil olmak üzere farklı müzelerde de SG teknolojilerinin sunduğu olanaklardan yararlanılmaktadır. Bu eğilime katılan müzelerden bir diğeri Finlandiya Ulusal Müzesi'dir. Sanal gerçeklik uygulaması ile müze ziyaretçileri R. W. Ekman'ın "The Opening of he Diet 1863 by Alexander II" tablosunun içinde yürüyerek 1863 y1lını geri dönüşlerinin canlandırılmasıdır (Resim 9). R.W. Ekman tarafından tuval üzerine yağlı boğa tekniği ile yapılan resimde Parlamento açılışı resmedilmiştir. Ekman, hayatının son beş yılında fotoğraflardan portre çizerek Turku'da yaşamışıtır (Kayhö, 1995).

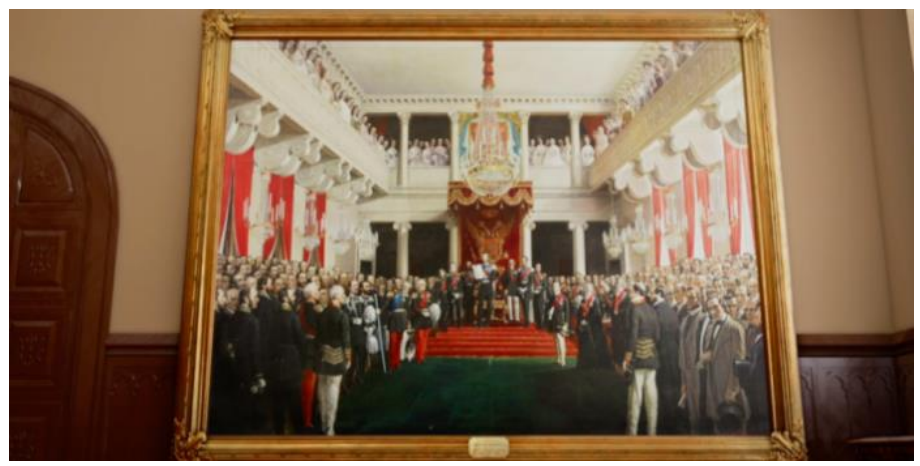

Resim 9. R.W. Ekman, (1863)

Kaynak: URL-8 (2020).

Sanal gerçeklik deneyimi ile uluslararası düzeyde deneyim sunarak olayların görselleştirilmesi daha fazlasını ziyaretçiye ulaşmaktadır (Resim 10). Serginin amac1, tarihi eserleri dijital bir dünya ile harmanlayarak ziyaretçilere tarihe doğru yürüdüğünü hissettirmektir. Sanal deneyimi, Finlandiya'da SG stüdyosu tarafından oluşturulmuştur. Şirket, Finlandiya'yı dünyadaki en sanal toplum haline getirmeyi misyon edinmiştir. Müze ziyaretçilerine resmin içine girme hissini sunmakla beraber Rus İmparator ve resimde tasvir edilen diğer karakterlerle konuşma firsatı sunmaktadır.

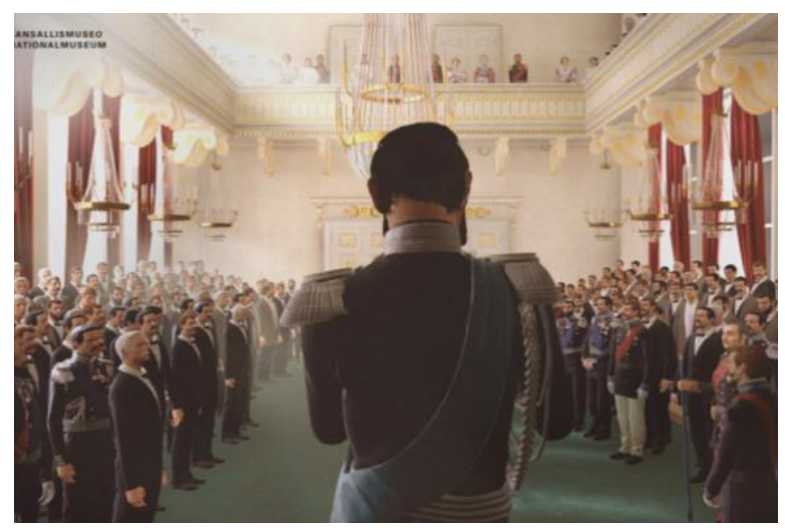

Resim 10. Finlandiya Ulusal Müzesi, Sanal Zaman Yolculuğu Sunuyor

Kaynak: URL-9 (2020).

SG'yi bir anlatım yöntemi olarak Dünya'da ilk kez Bergama antik şehri 3 boyutlu gezi sağlamaktadır (Resim 11). Son y1llarda verinin sayısal ortamda üç boyutlu modellenmesi, temsil amaçlı görselleştirilmesi ve sayısal ortamda deneyimlenmesine yönelik projeler yaygınlaşmaktadır. Batı Anadolu'da bulunan Bergama antik kentinde yürütülen "iVisit Anatolia: Tarih 3 Boyutlu Canlanıyor" projesi ile yapıların antik dönemdeki hallerini gösteren sanal gerçeklik simülasyonu hazırlanmıştır (Karabağ, 2017). Yapının, 3 boyutlu gezi uygulaması, Bergama`nın 4 antik alanı olan Zeus Sunağ1, Athena Tapınağı, Kızıl Avlu ve Asklepion alanlarını ziyaret edenlere, alanda yapıların orijinal halini akıllı 
telefonlar ve sanal gerçeklik kılıfları ile deneyimlenebilmektedir. Ancak bu çalışma kullanıcıya kısıtlı deneyim sağlamaktadır.

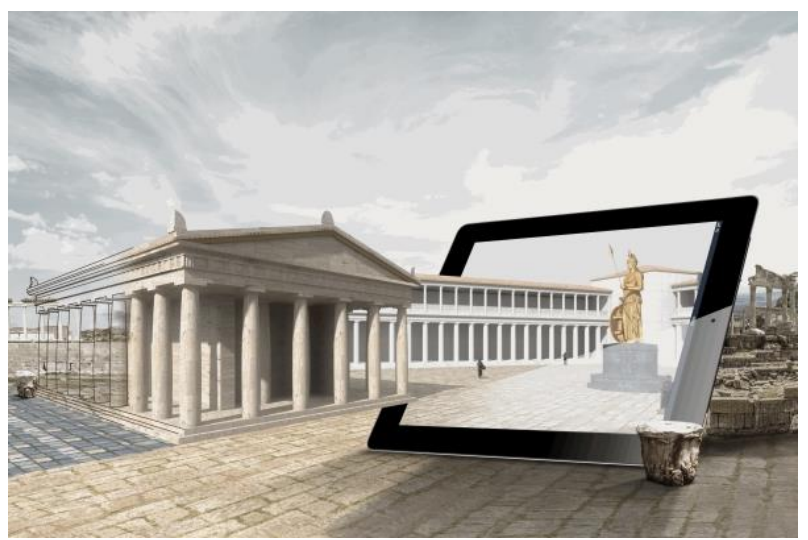

Resim 11. Bergama Antik Kenti uygulamas1

Kaynak: URL-10 (2021).

Sanal gerçeklik aygıtlarına kolay ulaşım yoluyla kullanıcı herhangi bir ortamda, sanal arkeolojik ortamda var olma duygusuna kapılabilmektedir (Bruno et al., 2010). Çatalhöyük'te yapılan çalışma ise diğer önemli bir projedir. Bu uzun soluklu arkeolojik araştırma örneğinde verinin toplanmasından analizine ve görselleştirilmesine kadar üç boyutlu arkeoloji yapılmaktadır (Forte et al., 2012). Yapılan kazıların kayıtlarının ve çıktılarının dijitalleştirilmesiyle başlayan süreçte, kazı alanının simülasyon aracıyla deneyimlenmesi ve Second Life gibi sanal gerçeklik ortamlarında alanın canlandırılması ve böylece daha geniş bir ziyaretçi profiline hitap etmesi sağlanmıştır. "Bir Kazı Hikayesi: Çatalhöyük" sergisi kapsamında sanal ortamda canlandırılan yapılar sanal gerçeklik cihazıyla deneyimlenebilmektedir (Lercari, 2017). Bergama örneğinden ayıran ise kısıtlı çevreden bağımsız sanal gerçeklik aygıtı ile yeniden canlandırılan mekanlarda gezinme imkanı sunulmaktadır (Resim 12).

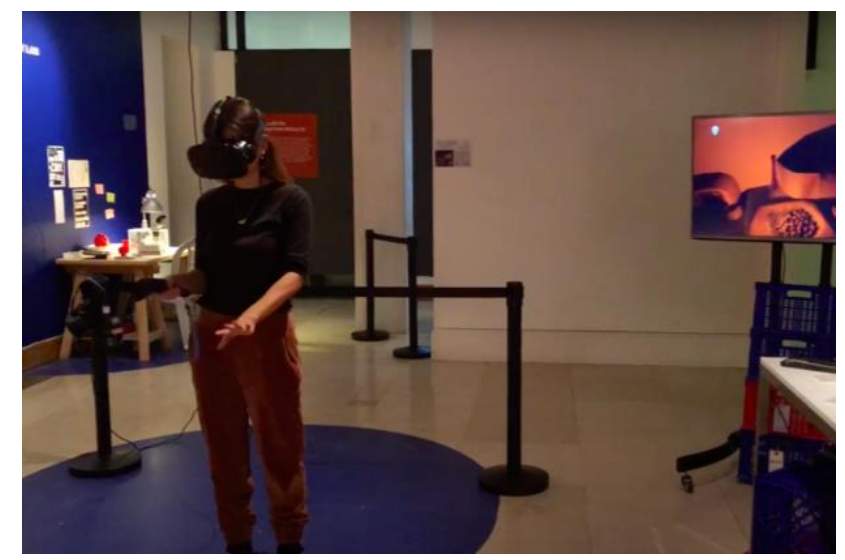

Resim 12. Bir Kazı Hikayesi Sergi’sinden deneyim

Kaynak: URL-11 (2021).

Diğer sanal gerçeklik teknolojisi temelinde oluşturulan çalışma ise 'VR Mersin' projesidir. Mersin Büyükşehir Belediyesi ve Mersin ve Çevresi Turizm Alanı Altyapı Hizmet Birliği (METAB) işbirliği ile gerçekleştirilen Tekno Mersin Projesi ile Mersin internet ortamında sanal tur yöntemi kullanılarak şehir tanıtılmaktadır (Ekici \& Güven, 2017). Proje kapsamında 4 dil seçeceği sunulmaktadır (Resim 13). 


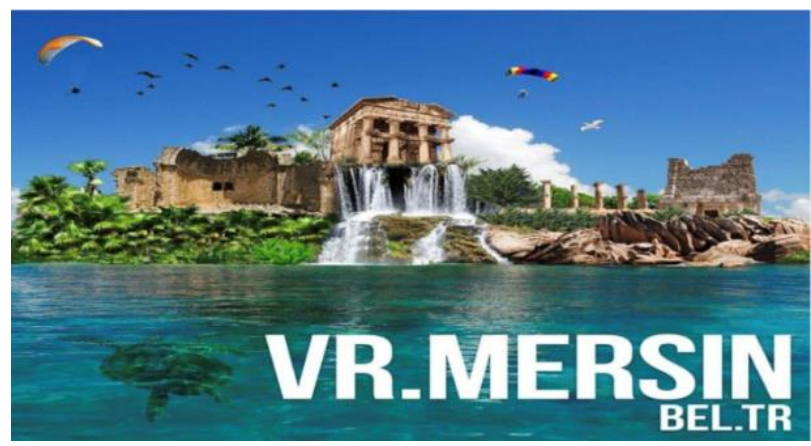

Resim 13. Mersin ili Sanal Gerçeklik Projesi

Kaynak: URL-12 (2021).

\section{KAPLUMBAĞA TERBIYYCCISI SANAL GERÇEKLIK UYGULAMASI KULLANICI DENEYIMLERİ VE DEĞERLENDİRME}

Pera Müzesinin, 15 yıldır koleksiyonunda bulundurduğu Osman Hamdi Bey'in meşhur tablosu 'Kaplumbağa Terbiyecisi sanal gerçeklikle (VR) alımlayıcısına sunuldu (Resim 14). Suna ve İnan Kıraç Vakfı tarafından desteklenen müzede açılan "Osman Hamdi Bey'in Dünyasına Yolculuk: Sanal Gerçeklik Deneyimi” başlıklı proje çerçevesinde Osman Hamdi Bey’in Kuruçeşme'deki çalışma odasının 1906 yılındaki hâlini, sanal gerçeklik ile tecrübe ederek teknolojinin sanatla buluşması sağlanmaktadır. Çeşitli fotoğraflardan ve vesikalardan faydalanılarak hazırlanan dijital odada dolaşarak Osmanlı ressamın şahsi eşyalarına, notlarına ve fotoğraflarına göz 3 boyutlu olarak dahil olunmaktadır. Bununla birlikte tanınmış ressamın, spatulasını elinize alarak "Kaplumbağa Terbiyecisi" tablosunun içerisine girilebilmektedir. Tabloya girdikten sonra eserde bulunan kaplumbağalara marul ikram ederek geçmiş ile bugün arasındaki mesafe kısalarak hafızlarımızda yer edinmiş bir tablo ile yakıdan bir bağ kurmuş oluyorsunuz. Bu tecrübe Pera Müzesi ziyaretçilerine sunulmaktadır.

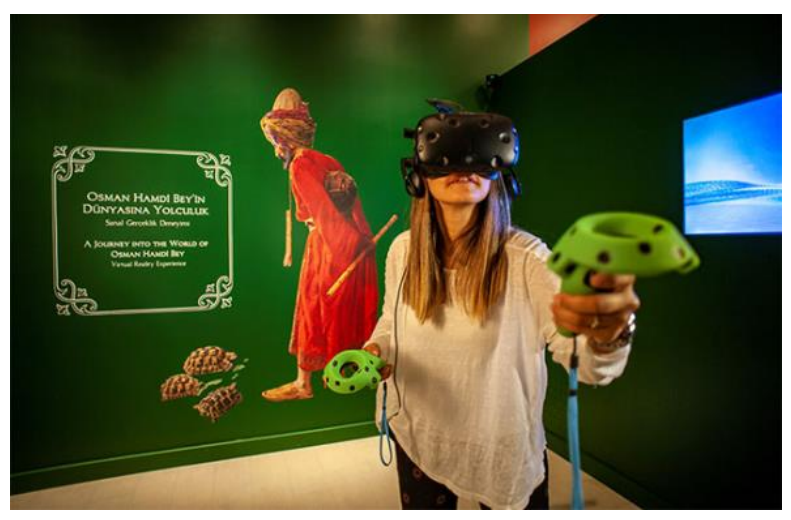

Resim 14. Osman Hamdi Bey’in 'Kaplumbağa Terbiyecisi sanal gerçeklikle (VR) alımlayıcısına sunuldu.

Kaynak: URL-13 (2021).

\section{Kaplumbağa Terbiyecisi 'Sanal Gerçeklik' Deneyimi Sonunda Tablo 2'deki Sorular Sorularak Cevapları}

Araştırma, nitel araştırma yöntemi e-posta (elektronik posta) aracılığıyla gerçekleştirilen e görüşme (elektronik-posta görüşme) tekniği ile gerçekleştirilmiştir. E-görüşmeler araştırmacı ve katılımcının yüz yüze görüştügü ortak bir mekânı ve mekânla sınırlanan zamanı gerektirmez, bilgisayar aracıllğıyla gerçekleştirilen iletişime dayanır (Linabary ve Hamel, 2017.99). Bu çalışmada Pera Müzesi'nde Kaplumbağa Terbiyecisi isimli tabloyu SG yolu ile deneyimleyen Görsel Sanatlar alanlarında uzman 6 
katılımcıya yöneltilen 4 soru ile desteklenmektedir. Çalışmaya katılan her bir kullanıcı sanal gerçeklik gözlügü kullanarak sanal gerçeklik ortamında (müzede) en az 10 dakika zaman geçirerek bir deneyim yaşamıştır. Müze ziyaretçilerinin tercihlerini, yorum ve görüşlerini görüşme yaparak sormak sınırlı sayı da kişiye ulaşılabilse bile, derin biçimde yorumların kazanılmasında faydalı bir araştırma yöntemi olarak görülmektedir. Soru sayısı 4'le sınırlı tutulurken 6 kullanıcının görüşüne başvurulmuştur. Soru içerikleri deneyimin sanatsal yönü, deneyimin SG açısından doğallığı ve atmosferi, sanata yeni bir katkı olarak SG deneyiminin devamlılığı konularını içermektedir. Bu soruların şekillenmesinde deneyimin kendisi, içeriğinde kullanılan alana katkısı, ve alandaki geleceğinin katılımcılar tarafından nasıl görüldüğü anlaşılması amaçlanmaktadır.

Görüşlerine yer verilen Tablo 2'deki katılımcılara 1. Soru ile “Osman Hamdi Bey'in Kaplumbağa Terbiyecisi adlı eserinin Sanal Gerçeklik deneyimine dönüşmesinin sanata katkısını nasıl değerlendiriyorsunuz?" konusunda ulaşılmak istenen, SG teknoloji ile üretilen eserlerde gerçeklik kavramı izafi olarak değerlendirilmektedir. Kurgulanmış ama gerçeklik açısından inandırıcı ortama dahil olduğu düşünülmektedir. SG deneyimlerinin sanat genelinde ve çalışmada incelenen Kaplumbağa Terbiyecisi özelinde görüşlerine yer verilmektedir. 2. Soru ile "Deneyiminizin gerçeklik (reality), sarmalama (immersive) ve var olma hali (presence) kavramları açısından değerlendirdiğinizde çalışmayı nasıl tanımlarsınız, açıklayınız? (güçlü, orta, zayıf)" konusunda SG' in temel kavramlarından yola çıkarak değerlendirilme yapılacaktır. Gerçeklik, duyuların etkin bir şekilde nasıl gerçeklik etkisi yaptığın, etkileşimin gerçekçi olması ve kişinin hissedebilmesi için orada olma hali kavramı üzerinden eseri tanımlanması hedeflenmektedir. 3. Soru "Deneyiminiz sırasında duyumsadı̆̆ınız atmosferi hangi sıfatlarla tanımlarsınız?” konusunda Osman Hamdi Bey'in Dünyasına Yolculuk başlıklı sanal gerçeklik projesi kapsamında ziyaretçiler sanatçının çalışma alanını ziyaret ederek, kitaplarından resim malzemelerine ve kişisel eşyalarına kadar birçok detayı yakından inceliyor, Kaplumbağa Terbiyecisi tablosunun içine girerek sanatçı ile göz göze geliyor. Deneyimlenen ortamın kullanıcılardaki karşı1lı̆ına ulaşmak öngörülmektedir. 4. Soru ile "Sanat eserlerini 3 boyutlu olarak sanal gerçeklikle deneyimlemek ister misiniz?" konusunda SG teknolojisi kullanarak üretilen sanat eserlerinin kullanıcı deneyimlerinin SG uygulaması ile üretilen sanat eserleri hakkında bulgulara ulaşılmak istenmektedir.

Tablo 2. Kullanıcı deneyimi ile ilgili yapılan görüşme soru ve cevapları

\begin{tabular}{|c|c|c|c|c|}
\hline \multirow{2}{*}{$\begin{array}{l}\text { Katılıme } \\
\text { lar }\end{array}$} & \multicolumn{4}{|c|}{ Sorular } \\
\hline & $\begin{array}{c}\text { Soru 1. Osman } \\
\text { Hamdi Bey'in } \\
\text { Kaplumbağa } \\
\text { Terbiyecisi adlı } \\
\text { eserinin Sanal } \\
\text { Gerçeklik } \\
\text { deneyimine } \\
\text { dönüssmesinin sanata } \\
\text { katkısını nasıl } \\
\text { değerlendiriyorsunuz } \\
?\end{array}$ & $\begin{array}{c}\text { Soru 2. Deneyiminizin } \\
\text { gerçeklik (reality), } \\
\text { sarmalama (immersive) } \\
\text { ve var olma hali } \\
\text { (presence) kavramları } \\
\text { açısından } \\
\text { değerlendirdiğinizde } \\
\text { çalışmayı nasıl } \\
\text { tanımlarsınız, } \\
\text { açıklayınız? (güçlü, orta, } \\
\text { zayıf) }\end{array}$ & $\begin{array}{c}\text { Soru } 3 . \\
\text { Deneyiminiz } \\
\text { sırasında } \\
\text { duyumsadığı } \\
\text { nız atmosferi } \\
\text { hangi } \\
\text { sıfatlarla } \\
\text { tanımlarsınız } \\
?\end{array}$ & $\begin{array}{c}\text { Soru 4. Sanat } \\
\text { eserlerini } 3 \\
\text { boyutlu } \\
\text { olarak sanal } \\
\text { gerçeklikle } \\
\text { deneyimlemek } \\
\text { ister misiniz? }\end{array}$ \\
\hline $\begin{array}{c}\text { Katılımeı } \\
1\end{array}$ & $\begin{array}{l}\text { Sanatın teknolojiyle iş } \\
\text { birliğinde olması, } \\
\text { Alımlayıcıyı salt bir } \\
\text { izleyiciden } \\
\text { deneyimleyiciye } \\
\text { dönüştürmesi ve } \\
\text { sanatın içine daha çok } \\
\text { çekebilmesi açısından } \\
\text { önemli buluyorum. }\end{array}$ & $\begin{array}{l}\text { Bu çalışma daha önceki } \\
\text { deneyimlediğim sanal } \\
\text { gerçeklik ve sanat } \\
\text { uygulamalarıyla } \\
\text { kıyasladığımda en etkili } \\
\text { olanlarından. Ortamın } \\
\text { atmosferi doğrudan içine } \\
\text { çekiyor ve orada olma } \\
\text { hissini kuvvetli biçimde } \\
\text { yansitıyor. Yalnızca gerçek } \\
\text { ortam etrafındaki sesleri }\end{array}$ & $\begin{array}{c}\text { Zamanda } \\
\text { yolculuk hissi, } \\
\text { bir bilim } \\
\text { kurgu } \\
\text { filminde } \\
\text { olmak gibi, } \\
\text { bir anda kendi } \\
\text { döneminden } \\
\text { çok daha eski } \\
\text { bir döneme } \\
\text { 1̧̧ılnlanma }\end{array}$ & $\begin{array}{c}\text { Sanat eserlerini } \\
3 \text { boyutlu } \\
\text { ortamda } \\
\text { deneyimlemek } \\
\text { isterim. Ancak } \\
\text { nitelikli işler } \\
\text { çerçevesinde } \\
\text { ve eserin aslını } \\
\text { bozuma } \\
\text { uğratmadan, } \\
\text { aurasını }\end{array}$ \\
\hline
\end{tabular}




\begin{tabular}{|c|c|c|c|c|}
\hline & & $\begin{array}{c}\text { duymasak ya da daha sessiz } \\
\text { bir ortamda deneyimlesek } \\
\text { daha etkili olurdu. } \\
\text { Kaplumbağaları besleme } \\
\text { kısmı eğlenceli bir } \\
\text { interaktiflik sağlasa da } \\
\text { gerçeklik hisini biraz } \\
\text { kırıyor. Bu bölüm belki } \\
\text { gelecekte daha ileri bir } \\
\text { teknolojiyle düzeltilebilir. } \\
\text { Ama genel olarak ortamın } \\
\text { atmosferi, bulunulan } \\
\text { odadaki duygular orada var } \\
\text { olma duygusunu } \\
\text { olabildiğince yaşatmaya } \\
\text { çalışıyor. }\end{array}$ & $\begin{array}{l}\text { duygusu. } \\
\text { Özellikle bir } \\
\text { sanatçının } \\
\text { çalışma } \\
\text { odasında } \\
\text { gitmek } \\
\text { büyüleyici } \\
\text { etkiyi } \\
\text { artırıyor. }\end{array}$ & $\begin{array}{c}\text { bozmadan } \\
\text { yapılan } \\
\text { çalişmaları } \\
\text { farklı gerçrklik } \\
\text { katmanlarıyla } \\
\text { deneyimlemek } \\
\text { isterim. }\end{array}$ \\
\hline $\begin{array}{l}\text { Katılımeı } \\
2\end{array}$ & $\begin{array}{l}\text { Sanatın günümüz } \\
\text { teknolojisine uyumu } \\
\text { açısından doğru } \\
\text { buluyorum. }\end{array}$ & $\begin{array}{l}\text { VR'ın son yılların güncel } \\
\text { bir konusu olması ve henüz } \\
\text { pek çok bilinmezi içinde } \\
\text { barındırması sebebiyle } \\
\text { "gerçekliği deneyimleme" } \\
\text { açısından eksiklikleri var. } \\
\text { Ancak bu deneyimde bu } \\
\text { eksiklikler büyük oranda } \\
\text { giderilmiş ve VR'ın } \\
\text { gerçekliğine dalma hissi } \\
\text { güçlendirilmişti. Ancak bir } \\
\text { derecelendirme } \\
\text { gerekiyorsa, VR'ın taşıdığı } \\
\text { potansiyelin çok güçlü } \\
\text { olması açıdan bu deneyimi } \\
\text { "orta seviye" bir deneyim } \\
\text { olarak düsünüyorum. }\end{array}$ & $\begin{array}{c}\text { Geçmişi } \\
\text { şimdiye } \\
\text { taşımış hissi. } \\
\text { İki zamanı } \\
\text { aynı anda } \\
\text { yaşama } \\
\text { duygusu } \\
\text { kesinlikle. }\end{array}$ & $\begin{array}{c}\text { Kesinlikle } \\
\text { isterim. Bu } \\
\text { çalışmayı da o } \\
\text { anlamda } \\
\text { önemli ve } \\
\text { kayda değer bir } \\
\text { gelişme olarak } \\
\text { görüyorum. }\end{array}$ \\
\hline $\begin{array}{c}\text { Katılımeı } \\
3\end{array}$ & $\begin{array}{l}\text { Sanat eserlerinin, } \\
\text { tasarımların, } \\
\text { sanatçıların ve } \\
\text { tasarımcıların daha } \\
\text { fazla kişiye ulaşması } \\
\text { ve akılda kalıcıllı̆ } \\
\text { açısından pozitif } \\
\text { değerlendiriyorum. }\end{array}$ & Orta & $\begin{array}{l}\text { Etkileyici, } \\
\text { akılda kalıcı } \\
\text { fakat soğuk, } \\
\text { ruhsuz }\end{array}$ & Evet \\
\hline $\begin{array}{l}\text { Katılımeı } \\
4\end{array}$ & $\begin{array}{l}\text { Oldukça etkili. Bir } \\
\text { sanat eserinin içine } \\
\text { girip, duyuları aktive } \\
\text { etmek onu anlamakta } \\
\text { büyük bir rol oynuyor. }\end{array}$ & Orta & $\begin{array}{l}\text { Gerçeklik } \\
\text { Yanılsaması }\end{array}$ & Kesinlikle evet. \\
\hline $\begin{array}{l}\text { Katılımeı } \\
5\end{array}$ & $\begin{array}{l}\text { Eserin akıllarda yer } \\
\text { etmesi anlamında } \\
\text { olumlu bulurken eserin } \\
\text { görünmeyen yanlarını } \\
\text { yorumlaması açısından } \\
\text { problemli buluyorum. }\end{array}$ & $\begin{array}{l}\text { Çalışmanın güçlü olduğunu } \\
\text { düşünüyorum. }\end{array}$ & $\begin{array}{c}\text { Etkileyici, } \\
\text { otantik ve hoş }\end{array}$ & İsterim \\
\hline
\end{tabular}




\begin{tabular}{|c|c|c|c|c|}
\hline $\begin{array}{c}\text { Katılıme } \\
6\end{array}$ & $\begin{array}{c}\text { Teknolojinin } \\
\text { gelişiminden payını } \\
\text { alan sanat izleyenin } \\
\text { rolünü dönüştürerek } \\
\text { deneyimleyici } \\
\text { olmasını } \\
\text { hedeflemektedir ve } \\
\text { sanatın alımlayıcı } \\
\text { üzerinde etkisinin } \\
\text { artmasını } \\
\text { sağlamaktadır. }\end{array}$ & $\begin{array}{l}\text { Uygulama açısından } \\
\text { etkileyici olmasıla birlikte } \\
\text { 'orta' derece olarak } \\
\text { değerlendirebilirim. }\end{array}$ & $\begin{array}{c}\text { An'1 yaşıyor } \\
\text { gibisiniz. }\end{array}$ & $\begin{array}{c}\text { Kesinlikle } \\
\text { ancak eserin } \\
\text { gücünün önüne } \\
\text { geçilmesi } \\
\text { kriterini de } \\
\text { değerlendirmek } \\
\text { gerekir. }\end{array}$ \\
\hline
\end{tabular}

Kaynak: Tanrikulu \& Karagöl (2020).

\section{Kaplumbağa Terbiyecisi Tablosunun Sanal Gerçeklik Deneyimi Sonrasında Görüşme Değerlendirme Sonuçları}

- Osman Hamdi Bey’in Kaplumbağa Terbiyecisi adll eserinin Sanal Gerçeklik deneyimine dönüşmesinin sanata katkısını nasıl değerlendiriyorsunuz? Sorusuna katılımcıların yorumu;

Sanatın teknolojiyle iş birliğinde olması, Alımlayıcıyı salt bir izleyiciden deneyimleyiciye dönüştürmesi ve sanatın içine daha çok çekebilmesi açısından önemli bulunduğunu ayrıca sanat eserlerinin, tasarımların, sanatçıların ve tasarımcıların daha fazla kişiye ulaşması ve akılda kalıcılığı açısından pozitif değerlendirildiği diğer taraftan Eserin akıllarda yer etmesi anlamında olumlu bulurken eserin görünmeyen yanlarını yorumlaması açısından problemli bulunulabileceği belirtilmektedir.

- Deneyiminizin gerçeklik (reality), sarmalama (immersive) ve var olma hali (presence) kavramlar açısından değerlendirdiğinizde çalışmayı nasıl tanımlarsınız, açıklayınız? (güçlü, orta, zayıf) sorusu yöneltilen katılımcılar; Çalışmanın deneyimlenen SG ve sanat uygulamalarıyla kıyasladı̆̆ında en etkili olanlarından ayrıca ortamın atmosferi gerçeklik hissine yakın olduğundan bahsedilmektedir. Deneyimleme esnasında sunulan eserdeki kaplumbağaları besleme deneyimi eğlenceli bir interaktiflik sağlasa da gerçeklik hissini kırdığ 1 düşünülmektedir. Eserde, teknolojinin gelişmesine paralel olarak insana ait duyuların karşılı̆̆ı bulunması beklenmektedir. Ayrıca, SG'nin son yılların güncel bir konusu olması ve henüz pek çok bilinmezi içinde barındırması sebebiyle "gerçekliği deneyimleme" açısından eksiklikleri bulunmakla birlikte deneyimdeki eksiklikler büyük oranda giderilmiş ve SG'nin gerçekliğine dalma hissi güçlendirilmiştir. Deneyimde bulunan katılımcilarda 4 kişinin 'orta' olarak değerlendirildiği genel olarak ortamın atmosferi, bulunulan odadaki duygular orada var olma duygusunu olabildiğince yaşattığı görüşü düşünülmektedir.

- Deneyiminiz sırasında duyumsadiğınız atmosferi hangi sıfatlarla tanımlarsınız? Sorusuna kat1lımcilardan zamanda yolculuk hissi, bir bilim kurgu filminde olmak gibi, bir anda kendi döneminden çok daha eski bir döneme ışınlanma duygusu ile birlikte özellikle bir sanatçının çalışma odasında gitmenin büyüleyici bir deneyim olarak açıklanmaktadır. Geçmişi şimdiye taşımış hissi ve iki zamanı aynı anda yaşama duygusunu barındırırken aynı zamanda etkileyici, akılda kalıcı fakat soğuk, ruhsuz olarak da belirtilmektedir. Bununla birlikte deneyimi hoş ve otantik sıfatları ile desteklenmektedir.

- Sanat eserlerini 3 boyutlu olarak sanal gerçeklikle deneyimlemek ister misiniz? sorusuna katılımcıların tamamının böyle bir deneyime ortak olma istekleri bulunduğu belirtilmektedir. Ancak nitelikli işler çerçevesinde ve eserin aslını bozuma uğratmadan, aurasını bozmadan yapılan çalışmaları farklı gerçeklik katmanlarıyla deneyimlemek istediklerini düşünülmektedir. 


\section{SONUÇ}

Son yıllarda, sanal gerçeklik (SG) kullanımı önemli ölçüde artarak, yaşantımızın pekçok farklı alanında kendine yer bulmaktadır. Türkiye'de diğer ülkelerde olduğu gibi SG’nin oyun sektörünün etkisiyle ilk tasarım örneklerinin görüldüğü bilinmektedir. Kurumsal anlamda yükselen bir değer olarak müzeler teknolojik araçlardan yararlanmaktadır. Bu araçların en dikkat çeken yeniliklerinde biri de sanal gerçeklik teknolojisidir. Ak1llı telefonlar, tabletler, bilgisayarlar, çok boyutlu görsel-işitsel cihazlar, vb. yeni aletler ve uygulamalardan yararlanan müzeler için yeni etkileşim imkanları ortaya çıkmıştır. İnternet ile entegre bir şekilde çalışan cihazlar sayesinde gelişmiş ve gerçek gibi görünen sanal ortamların oluşmasına imkan sağlanmıştır. Böylece, artırılmış gerçeklik ve sanal gerçeklik teknolojisi müze ekosistemine dahil olmuştur. SG, eğitim, tıp, eğlence, yiyecek-içecek, pazarlama, askeri, mimari, müze vb. alanlarda kullanılmaktadır. Teknolojik sergileme yöntemleri müze sektörüne de dahil edilerek, ziyaretçilerin sanatı deneyimleme ve algılamasını biçimsel olarak etkilemektedir. Sanal gerçeklik gözlüğü kullanıcıyı tamamen yeniden üretilmiş sanal bir ortama aktarmaktadır. Kulaklık ve gözlükle algıyı değiştiren bu tasarım kullanıcısına yeni bir ortamda olmayı ve kendi gerçekliğinden soyutlanmayı vaat etmektedir.

Dünyadaki ziyaretçi sayısının ve tanınırlığının fazla olduğu müzelerden örnekler seçilerek çalışmaya dahil edilmiştir. Louvre (Paris), Tate Modern (Londra), Finlandiya Ulusal Müzesi (Finlandiya) ülkelerinde bulunan müzelerden örnekler incelenmekle birlikte Türkiye'den kültürel etkinliklerden örneklere yer verilmiştir. Müzelerin teknolojik yenilikleri, benimseme ve dijital çağın zorluklarına uyum sağlama girişimiyle müze ortamlarında sanal gerçeklik kullanımında önemli bir artış olmuştur. Bu çalışmada Pera Müzesi'nde Kaplumbağa Terbiyecisi isimli tabloyu SG yolu ile deneyimleyen görsel sanatlar alanlarında uzman 6 katılımcıya yöneltilen 4 soru ile desteklenmektedir. Çalışmaya katılan her bir kullanıcı sanal gerçeklik gözlüğü kullanarak sanal gerçeklik ortamında (müzede) en az 10 dakika zaman geçirerek bir deneyim yaşamıştır. Müze ziyaretçilerinin tercihlerini, yorum ve görüşlerini görüşme yaparak sormak sınırlı sayıda kişiye ulaşılabilse bile, derin biçimde yorumların kazanılmasında faydalı bir araştırma yöntemi olarak görülmektedir. Soru sayısı 4'le sınırlı tutulurken 6 kullanıcının görüşüne başvurulmuştur.

Osman Hamdi Bey imzalı Kaplumbağa Terbiyecisi adlı tablonun sanal gerçeklik deneyimine dönüşmesi sanatın teknolojiyle iş birliğinde olması, alımlayıcıyı sadece bir izleyici olmaktan çıkarıp ayrıca bir deneyimleyiciye dönüştürmesi ve eserin içine daha dahil etmesi açısından önem taşımaktadır. Teknolojinin hızla ilerlemesini etkisiyle her alanda olduğu gibi sanat alanında da dijitalleşme kaygısı ve çabası anlaşılır görünmektedir. Bu dijitalleşme durumu eseri deneyimleme, akılda kalıcılığı artırması ve duyuları aktive etmesi bakımından olumlu olduğu düşünülmektedir. Ancak bunun yanında eserin bize sunulmayan bölümlerinin yorumlanması açısından problemli olarak düşünülebilir. Sanat eserinin, sanal gerçeklik deneyimi ile geçmişi, şimdiye taşıması durumu -iki zamanı aynı anda yaşama duygusunu yaşatması- hem olumlu hem de olumsuz çağrışımları olan bir tecrübe olarak değerlendirilebilir. 


\section{KAYNAKÇA}

Bruno, F., Bruno, S., De Sensi, G., Luchi, M. L., Mancuso, S., Muzzupappa, M. (2010). From 3D Reconstruction to Virtual Reality: A Complete Methodology for Digital Archaeological Exhibition, Journal of Cultural Heritage, Say1 11:1

Demirezen, B. (2019). Artırllmış Gerçeklik ve Sanal Gerçeklik Teknolojisinin Turizm Sektöründe Kullanılabilirliğ i Üzerine Bir Literatür Taraması. Uluslararsı Global Turizm Araştırmaları Dergisi. Cilt:3 Say1:1

Ekici, R. ve Güven, A. (2017). Sanal Gerçeklik Teknolojisinin Turizm Endüstrisindeki Rolü, Avrasya Bilimler Akademisi Sosyal Bilimler Dergisi, Özel Sayı

Erbay, M. (2011). Müzelerde Sergileme ve Sunum Tekniklerinin Planlanması. Beta Yayınları, İstanbul

Forte, M., Dell’Unto, N., Issavi, J., Onsurez, L., Lercari, N. (2012). 3D Archaeology at Çatalhöyük. International Journal of He- ritage in the Digital Era, Say1 1:3.

Gombrich, E.H. (2013). Sanatın Öyküsü. Remzi Kitabevi. İstanbul

Karabağ, N. E. (2017). Dijital Teknolojilere Adapte Olan Bir Antik Kent: Bergama. Mimarlık, Sayı 398

Kayhö, U. (1995). Painted and Photographed Portraits in Finland, 1839-1870. University of Jyvaskyla. Finlandiya

Lercari, N. (2017). 3D Visualization and Reflexive Archaeology: A virtual Reconstruction of Çatalhöyük History Houses. Digital Applications in Archaeology and Cultural Heritage, Say1 6.

Linabary, R. J. ve Hamel, A. S. (2017). Feminist Online Interviewing: Ongoing İssues Of Power, Resistance And Reflexivity in Practice. Feminist Review No:115, ss. 97-113.

Hourticq, L. (1967). Burhan Toprak, Sanat Şaheserleri. Güzel Sanatlar Akademisi Yayınları, İstanbul, s. 318, 319).

Martirosov, S. and Kopecek, P. (2017). Virtual Reality and Its Influence on Training and Education Literature Review. 28th Daaam International Symposium On Intelligent Manufacturing And Automation (www.researchgate.net/publication) (erişim: 21-09-2020)

Özuyar, A. (2017). Sessiz Dönem Türk Sinema Tarihi (1895-1922). Yapı Kredi Kültür Sanat Yayınc1lı, İstanbul.

Sutherland, I. (1968). A head Mounted Three Dimensional Display. Proceedings of the AFIPS Fall Joint Computer Conference, Washington, DC, Thomson Books s. 757-764. (www.cise.ufl.edu/research/lok/teaching/ve-s07/papers/sutherland-headmount.pdf [21-09-2020].

Xinxiong L, Zhang1, J. Hou1, G. Wang, Z. (2018). Virtual Reality and Its Application in Military. $2^{\text {nd }}$ International Symposium on Resource Exploration and Environmental Science IOP Publishing IOP Conf. Series: Earth and Environmental Science (https://www.researchgate.net) (erişim: 21-09-2020)

Yengin, D. ve Bayrak, T. (2017). Sanal Gerçeklik VR. İstanbul: Der Yayınları.

Yılmaz, E. (2010). Sanayi Toplumunda Sanatın İşlevselliği. Elektronik Sosyal Bilimler Dergisi. (9) 33, s. 334-347.

\section{ELEKTRONIKK KAYNAKLAR}

URL-1: canon.com.cy/view/laterna-magica Erişim Tarihi: 17.09.2020

URL-2: https://www.historyofinformation.com/ Erişim Tarihi: 17.09.2020

URL-3: https://www.youtube.com/watch?v=KfCMami0j7o) Erişim Tarihi: 11.01.2020

URL-4: www.louvre.fr/ Erişim Tarihi: 22.12.2020

URL-5: https://arts.vive.com/us Erişim Tarihi: 17.09.2020 - 22.12.2020 
URL-6: codemodeon.com.tr Erişim Tarihi: 13.12.2020

URL-7: tate.org.uk Erişim Tarihi: 18.09.2020

URL-8: vrfocus.com Erişim Tarihi: 25.12.2020

URL-9: vrfocus.com, Erişim Tarihi: 18.09.2020

URL-10: bilkom.com.tr Erişim Tarihi: 9.01.2021

URL-11: anamed.ku.edu.tr Erişim Tarihi: 3.02.2021

URL-12: vr.mersin.bel.tr Erişim Tarihi 5.01.2021

URL-13: Pera Müzesi Erişim Tarihi: 1.01.2021

\section{Atıf için:}

Tanrıkulu, B. ve Karagöl, A. (2021) Müzede Sanal Gerçeklik Uygulamaları: Bir Örnek Çalışma Olarak Kaplumbağa Terbiyecisi. Yeni Medya Elektronik Dergisi, 5 (2), 95-111 